3 Ng FM, Bornstein J, Pullin CE, Bromley JO, MacCauley SL. The minimal amino-acid sequence of the insulin potentiating effect of fragments of human growth hormone: its mechanism of action. Diabetes 1980;29:782-7.

4 Caygill C, Aylward C, Dandona P. Insulin antagonism of growth hormone on adipocyte lipogenesis. Biochem Soc Trans 1981;9:473-4.

5 MacGorman LR, Rizza RA, Gerich JE. Physiological concentrations of growth hormone exert insulin-like and insulin-antagonistic effects on both hepatic and extrahepatic tissues in man. f Clin Endocrinol Metab 1981;53:556-9.

(Accepted 4 November 1986)

Departments of Endocrinology and Chemical Pathology and Human Metabolism, Royal Free Hospital and School of Medicine, London NW3 2QG

V A FONSECA, MD, MRCP, senior registrar in diabetes and endocrinology

P DANDONA, DPHIL, MRCP, director of metabolic unit and physician in charge of diabetic service

C W H HAVARD, DM, FRCP, consultant physician and endocrinologist

Correspondence to: Dr Havard.

\section{Effect of the pollen season on nasal mast cells}

The number of pollen grains necessary to produce rhinitis in patients with hay fever decreases as the pollen season progresses-a phenomenon known as nasal priming and usually attributed to an increase in the non-specific membrane for each of the volunteers in July, October, and January. Not only was there an increase in the total numbers of mast cells in both the epithelium and the lamina propria in July 1985 compared with October but there was also a significant increase in the proportion of mast cells present in the epithelium in July 1985 compared with January $1986(\mathrm{p}<0.05)$.

\section{Comment}

The results of this study show that there was an eightfold increase in the number of mast cells in the nasal mucous membrane of patients with seasonal allergic rhinitis in the summer compared with that during the winter months and that the proportion of cells in the surface epithelial layer increased fourfold. As our patients suffered from symptoms during only the grass pollen season these changes in the number and site of the mast cells were probably related to natural exposure to the allergen. Recently, Enerbach et al showed migration of mast cells to the nasal epithelium during the birch pollen season in Scandinavia ${ }^{2}$ but did not find an increase in the total number of mast cells in the nasal mucous membrane at the height of the pollen season. Mast cells are rarely, if ever, found in the epithelium of patients who do not have rhinitis, but the total number in the nasal mucous membrane is similar to that in patients with seasonal allergic rhinitis outside the pollen season. ${ }^{3}$

Treatment that prevents the accumulation of mast cells in the nasal epithelium could be effective in treating allergic rhinitis as higher pollen counts would probably be required to trigger symptoms. Indeed, the results of recent studies of human skin have shown that potent topical corticosteroids can cause a depletion in the number of mast cells, ${ }^{4}$ and intranasal corticosteroids, which are effective in treating allergic rhinitis, ${ }^{5}$ may act in this way.

Number (\%) of mast cells per $\mathrm{mm}^{3}$ in nasal mucous membranes

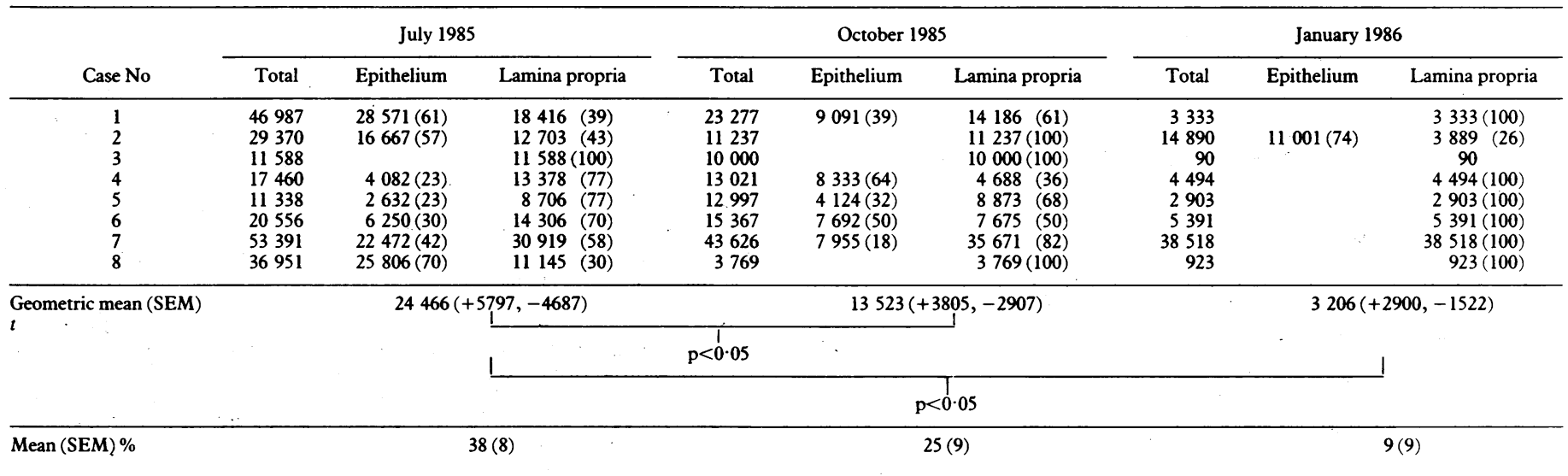

reactivity of the nasal mucosa. ${ }^{1} \mathrm{~A}$ similar effect could result from an increase, particularly in the superficial epithelial cell layer, in the number of mast cells sensitised by specific immunoglobulin $\mathrm{E}$ against grass pollen. We studied the effect of the pollen season on the total number of mast cells in the nasal mucous membrane and the proportion present in the epithelium.

\section{Subjects, methods, and results}

Eight volunteers (six women, two men; mean age 32) all had at least a five year history of rhinitis during only the grass pollen season. The results of skin prick tests were positive (weal $>3 \mathrm{~mm}$ ) with group $\mathbf{B}_{2}$ mixed grass pollen $2 \cdot 5 \%$ weight/volume and negative with Dermatophagoides pteronyssinus $1 \cdot 2 \%$ weight/volume (Bencard, Brentford, United Kingdom). They did not take any drugs for their rhinitis during the grass pollen season (May-August). Informed consent was obtained from all volunteers for this study, which had the approval of the district ethical committee.

Nasal biopsy samples about $4 \mathrm{~mm}^{3}$ in size were obtained from the inferior turbinate with modified Grünwald punch biopsy forceps five minutes after the topical application of $10 \%$ xylocaine. Samples were obtained from all volunteers in July 1985 at the height of the grass pollen season, in October after the season, and in January 1986 in midwinter. The coded biopsy samples were fixed in Carnoy's solution and stained with $\alpha$-napthol AS-D chloracetate esterase stain (Sigma). The area of the whole section was measured by planimetry. Each mas cell was counted and the number of mast cells per $\mathrm{mm}^{3}$ of nasal tissue calculated. Statistical analysis was by Wilcoxon's signed rank test and Student's paired $t$ test. The table shows the total number of mast cells per $\mathrm{mm}^{3}$ of nasal mucous
This research was supported by the Asthma Research Council.

1 Connell JT, Sherman W. Quantitative intranasal pollen challenges. III. The priming effect in allergic rhinitis. J Allergy 1969;43:33-44.

Enerbach L, Pipkorn U, Granerus G. Intraepithelial migration of nasal mucosal mast cells in hay fever. Int Arch Allergy Appl Immunol 1986;80:44-51.

3 Gomez E, Corrado OJ, Baldwin DL, Swanston AR, Davies RJ. Direct in vivo evidence for mast cell degranulation during allergen induced reactions in man. $\mathcal{f}$ Allergy Clin Immunol (in press).

4 Larker R, Schechter NM. Cutaneous mast cell depletion resalts from topical corticosteroid usage. f Immunol 1985;135:2368-73.

5 Mygind N. Topical corticosteroid treatment for allergic rhinitis and allied conditions. Clin Otolaryngol 1982;7:343-52.

(Accepted 9 October 1986)

\section{St Bartholomew's Hospital, London EC1}

$M$ VIEGAS, MB, MRCP, research registrar, academic department of respiratory medicine

E GOMEZ, MSC, PHD, research student, academic department of respiratory medicine

J BROOKS, FRCS, registrar, ear, nose, and throat department

D GATLAND, FRCS, registrar, ear, nose, and throat department

R J DAVIES, MD, FRCP, reader in respiratory medicine, academic department of respiratory medicine

Correspondence to: Dr Davies. 